\title{
Does the composition of toothpaste affect the tooth resistance to erosion/abrasion
}

\section{processes?}

A composição do creme dental afeta a resistência dlo dente aos processos de erosão / abrasão?

¿La composición de la pasta de dientes afecta la resistencia de los dientes a los procesos de erosión / abrasión?

Received: 01/27/2022 | Reviewed: 01/31/2022 | Accept: 02/03/2022 | Published: 02/05/2022

Bruna Ribeiro Luz

ORCID: https://orcid.org/0000-0002-9001-8428 Universidade do Vale do Paraíba, Brazil

E-mail: brunarluz@gmail.com

Gustavo Henrique Faria Silva

ORCID: https://orcid.org/0000-0003-1029-1350 Universidade do Vale do Paraíba, Brazil E-mail: gustavohfaria@live.com

Marcelo Henrique Pereira Marques da Silva ORCID: https://orcid.org/0000-0002-7617-9858 Universidade do Vale do Paraíba, Brazil E-mail:mh.marques.o@gmail.com Vinicius Silva Laurindo

ORCID: https://orcid.org/0000-0002-6981-6580 Universidade do Vale do Paraíba, Brazil E-mail: vini.slaurindo@gmail.com Vanessa Borelli Seefeldt

ORCID: https://orcid.org/0000-0002-7534-1999 Universidade do Vale do Paraíba, Brazil E-mail: vaseefeldt@hotmail.com

Sidnei Nahórny

ORCID: https://orcid.org/0000-0002-7490-6249 Universidade do Vale do Paraíba, Brazil E-mail: unisidnei@yahoo.com.br

Luís Eduardo Silva Soares

ORCID: https://orcid.org/0000-0001-9360-7407 Universidade do Vale do Paraíba, Brazil E-mail: lesoares@univap.br

\begin{abstract}
This study aimed to evaluate the tooth after brushing with toothpaste containing or not active compounds and with different fluoride concentrations after erosion to establish and compare the effectiveness of each dentifrice in its use. Enamel, E ( $\mathrm{n}=36)$ and dentin, D ( $\mathrm{n}=36)$ bovine specimens were treated with artificial saliva (AS - control), fluoridated dentifrice (FD), $8 \%$ arginine (AR), and calcium silicate (CS). The samples $(n=72)$ were subjected to cycles of demineralization (orange juice) followed by remineralization (saliva) and then tooth brushing (AR, FD and CS). The above cycle was repeated $3 \times /$ day for five days. Micro energy-dispersive X-ray fluorescence spectrometry $(\mu-$ EDXRF), roughness testing and scanning electron microscopy (SEM) were performed. The mean of roughness values $(\mathrm{Ra}, \mu \mathrm{m})$ were E-AS, 0.20; E-FD, 0.15; E-AR, 0.18; E-CS, 0.18; D-AS, 0.31; D-FD, 0.30; D-AR, 0.37; D-CS, 0.44. The SEM images showed a clear loss of tooth substance in AS and FD treatments. A significant positive mineral variation was observed on the dentin after brushed with AR ( $p<0.05)$. The FD dentifrice minimized the erosive effects of the orange juice. Arginine and calcium silicate could improve dental protection by the deposition of a surface layer of deposits. Different active compounds resulted in diverse degrees of protection regarding the type of substrate. The high concentration of fluoride and the inclusion of active compounds improves the dentifrice protection level.
\end{abstract}

Keywords: Compound; Dentifrices; Tooth abrasion; Demineralization; Fluorides.

\section{Resumo}

Este estudo teve como objetivo avaliar a estrutura dental após a escovação com dentifrício contendo ou não composto ativo e com diferentes concentrações de flúor após a erosão para estabelecer e comparar a eficácia de cada dentifrício em seu uso. Amostras de esmalte, $\mathrm{E}(\mathrm{n}=36)$ e dentina, $\mathrm{D}(\mathrm{n}=36)$ bovinos foram tratadas com saliva artificial (AS controle), dentifrício fluoretado (FD), arginina 8\% (AR) e silicato de cálcio (CS). As amostras $(\mathrm{n}=72)$ foram submetidas a ciclos de desmineralização (suco de laranja) e remineralização (saliva) seguidos de escovação dentária 
simulada (AR, FD e CS). O ciclo acima foi repetido $3 \times /$ dia durante cinco dias. Foram realizados espectrometria de microfluorescência de raios X por energia dispersiva ( $\mu$-EDXRF), teste de rugosidade e microscopia eletrônica de varredura (MEV). A média dos valores de rugosidade $(\mathrm{Ra}, \mu \mathrm{m})$ foram E-AS, 0,20; E-FD, 0,15; E-AR, 0,18; E-CS, 0,18; D-AS, 0,31; D-FD, 0,30; D-AR, 0,37; D-CS, 0,44. As imagens MEV mostraram uma clara perda de substância dentária nos tratamentos AS e FD. Uma variação mineral positiva significativa foi observada na dentina após escovação com AR ( $\mathrm{p}<0,05)$. O dentifrício FD minimizou os efeitos erosivos do suco de laranja. A arginina e o silicato de cálcio podem melhorar a proteção dentária pela camada superficial de depósitos. Diferentes compostos ativos resultaram em diversos graus de proteção em relação ao tipo de substrato. A alta concentração de flúor e a inclusão de compostos ativos melhora o nível de proteção do dentifrício.

Palavras-chave: Composto; Dentifrícios; Abrasão dentária; Desmineralização; Fluoretos.

\section{Resumen}

Este estudio tuvo como objetivo evaluar el diente después del cepillado con pasta de dientes que contenga o no compuesto activo y con diferentes concentraciones de flúor después de la erosión para establecer la efectividad de cada dentífrico. Se trataron muestras bovinas de esmalte, E $(n=36)$ y dentina, $D(n=36)$ con saliva artificial (AS control), dentífrico fluorado (FD), arginina al $8 \%$ (AR) y silicato de calcio (CS). Las muestras $(n=72)$ fueron sometidas a ciclos de desmineralización (jugo de naranja) seguido de remineralización (saliva) y luego cepillado de dientes (AR, FD y CS). El ciclo anterior se repitió $3 \times$ /día durante cinco días. Se realizaron espectrometría de micro fluorescencia de rayos X de dispersión de energía ( $\mu$-EDXRF), pruebas de rugosidad y microscopía electrónica de barrido (SEM). La media de los valores de rugosidad $(\mathrm{Ra}, \mu \mathrm{m})$ fueron E-AS, 0,20; E-FD, 0,15; E-AR, 0,18; E-CS, 0,18; D-AS, 0,31; D-FD, 0,30; D-AR, 0,37; D-CS, 0,44. Las imágenes SEM mostraron pérdida de sustancia dentaria en los tratamientos de EA y FD. Se observó una variación mineral positiva significativa en el grupo D-AR (p <0.05). El dentífrico FD minimizó los efectos erosivos. La arginina y el silicato de calcio podrían mejorar la protección dental mediante una capa superficial de depósitos. Diferentes compuestos activos dieron como resultado diversos grados de protección con respecto al tipo de sustrato. La alta concentración de flúor y la inclusión de compuestos activos mejora el nivel de protección del dentífrico.

Palabras clave: Compuesto; Dentífricos; Abrasión de los dientes; Desmineralización; Fluoruros.

\section{Introduction}

Dental erosion is a multifactorial condition that results in the chronic loss of dental structure caused by the chemical dissolution of minerals by acids. Acids may have intrinsic or extrinsic origin without bacterial involvement (Kyaw et al., \& Tagami, 2018; Maltarollo et al., 2020; ten Gate \& Imfeld, 1996).

The source of extrinsic acids is mainly from diet containing acidic food (citrus fruits, grapes, sour apples, vinegar) and drinks (soft drinks, carbonated beverages, fruit juices, teas, wine) (Bartlett, 2006; Fita \& Kaczmarek, 2016; Lussi \& Jaeggi, 2006) or acidic oral medication (Bartlett, 2006; Gomes et al., 2017, 2018). Intrinsic sources are mainly from acidic gastroesophageal reflux disease and vomiting (Fita \& Kaczmarek, 2016; West et al., 2017).

The change in people's lifestyle in recent years led to an increase in the consumption of acidic drinks, associating this fact to a higher prevalence of dental erosion (Ferreira et al., 2015). Due to the irreversibility of erosive tooth wear, preventive measures are essential (Ferreira et al., 2015).

Usually, the clinical procedure used for the prevention and treatment of dental erosion involves the association of the restriction of contact with erosive agents and the use of products containing fluoride in its composition. Topical fluoride pretreatment is used in the prevention of erosion. However, fluoride is only partially efficient and requires an intensive fluoridation regime to achieve significant protection (Ganss et al., 2004).

Measures to protect or to allow the increase in the tooth resistance after erosive conditions or mechanical impacts are relevant as hygiene measures. In this case, dentifrices containing different active agents may be helpful (de Queiroz et al., 2021; Magalhaes et al., 2014; Nova et al., 2021).

Current commercially available dentifrices based on formulae containing $8 \%$ arginine and calcium carbonate combined with sodium monofluorophosphate (MFP) were tested in dentin (Olley et al., 2012; Poggio et al., 2017; Poggio et al., 2014) and enamel erosion (Lombardini et al., 2014; Oliveira et al., 2019; West et al., 2017) and they offer some degree of 
protection or remineralization.

Oliveira et al. (2019) compared a dentifrice containing $1.5 \%$ arginine, $1450 \mathrm{ppm}$ of fluoride, and sodium MFP in insoluble calcium to a conventional dentifrice containing $1450 \mathrm{ppm}$ of fluoride and a dentifrice without fluoride. The authors concluded that arginine-based dentifrices increase the microhardness of sound and enamel carious lesions.

Recently, a calcium-silicate dentifrice was described with indications for treatment of dental erosion. It consists of a specific association of calcium silicate and sodium phosphate salts with fluoride ions (Crastechini et al., 2018). Dentifrices formulated with combinations of SMFP, arginine, and calcium-silicate have been shown to provide some degree of protection against dental erosion (Sullivan et al., 2014; Sun et al., 2014; Wood et al., 2018). Sun and others (2014) showed that brushing with toothpaste formulation containing calcium silicate resulted in hydroxyapatite deposition on the surface of the demineralized enamel, both in vitro and in situ. Poggio et al. (2017) tested dentifrices based on calcium silicate and hydroxyapatite in dentin after demineralization in soft drink and found that those protective pastes showed less weight loss due to the acidic challenge. Wood et al. (2018) tested the effectiveness of calcium silicate phosphate toothpaste in reducing surface softening in the early stages of enamel erosion. The results showed that the specimens treated with the calcium silicate phosphate toothpaste softened less than those treated with other fluoridated or non-fluoride tooth-pastes (Wood et al., 2018).

Thus, the current study aims to evaluate the tooth features after brushing with toothpaste containing or not active compounds and with different fluoride concentrations after erosion to establish and compare the effectiveness of each dentifrice in its use. The initial hypothesis is that significant changes in the eroded enamel and dentin surface would be observed between the treatments.

\section{Methodology}

\subsection{Experimental design}

Twenty bovine teeth were selected to prepare enamel (E) and dentin (D) samples. Seventy-two bovine teeth samples were assigned to the following experimental groups: artificial saliva (AS - control), fluoridated dentifrice, $1100 \mathrm{ppm}$ F (FD), arginine-based dentifrice, $1450 \mathrm{ppm}$ F (AR) and calcium silicate-based dentifrice, $1450 \mathrm{ppm}$ F (CS). The specimens were submitted to erosion (ERO) or erosion plus abrasion (ERO + ABR). The products, manufacturers, and components of materials used in this study are listed in Table 1. The factors studied were: type of dentifrice ( 3 types) and conditions ( 2 types: ERO and $\mathrm{ERO}+\mathrm{ABR})$. The inorganic content, surface roughness and morphology of the tooth were analyzed as response variables.

\subsection{Sample preparation}

The Ethics Committee of the Universidade do Vale do Paraiba approved this study (A02/CEUA/2016). Twenty sound permanent bovine incisors were selected and disinfected in aqueous $0.1 \%$ thymol solution ("Nostrafórmula" Compounding Pharmacy, São José dos Campos, SP, Brazil) (Soares et al., 2009). Forty bovine teeth were selected to prepare enamel and dentin samples. The roots were sectioned from crowns through the cementoenamel junction (labio-lingually and perpendicularly to the long axis) using a low-speed water-cooled diamond saw (speed of $\sim 400 \mathrm{rpm}$, mass of $\sim 100 \mathrm{~g}$, Isomet1000, Buehler, Lake Bluff, IL, USA). Root dentin was sectioned again in the middle resulting in two specimens per tooth ( $\mathrm{n}=40, \sim 7 \mathrm{~mm}$ long, $7 \mathrm{~mm}$ wide, and $6 \mathrm{~mm}$ thick) (Nahorny et al., 2017). Next, the crowns were sectioned to obtain two enamel specimens per tooth ( $\mathrm{n}=40, \sim 8 \mathrm{~mm}$ long, $8 \mathrm{~mm}$ wide, and $4 \mathrm{~mm}$ thick) (Raimundo Nonato Silva Gomes et al., 2017). All the 80 slabs were ground and polished to produce parallel surfaces (labial and lingual sites) with wet 600 and 1500grit silicon carbide paper (Arotec, Cotia, SP, Brazil) at 150 rpm (Metaserv 2000, Buehler, Lake Bluff, IL, USA). After each polishing step, the specimens were cleaned in an ultrasonic device with de-ionised water for $10 \mathrm{~min}$. to remove any debris (Maxiclean 1450, Merse, Campinas, SP, Brazil). 
Table 1: Description of experimental groups with the products used and respective composition.

\begin{tabular}{|c|c|c|c|}
\hline CONDITION & GROUP & PRODUCT & ACTIVE INGREDIENT-BASIC COMPOSITION- \\
\hline ERO & $\begin{array}{l}\text { E-AS } \\
\text { D-AS }\end{array}$ & $\begin{array}{l}\text { Control - Artificial saliva } \\
\text { ("Nostrafórmula" } \\
\text { Compounding Pharmacy, São } \\
\text { José dos Campos, SP, Brazil) }\end{array}$ & $\begin{array}{l}\left.1.5 \mathrm{mmol} \mathrm{L}-1 \mathrm{Ca}^{-} \mathrm{NO}_{3}\right)_{2} \mathrm{H}_{2} \mathrm{O} ; 0.9 \mathrm{mmol} \mathrm{L}^{-} 1 \mathrm{Na}_{2} \mathrm{HPO}_{4} \\
2 \mathrm{H}_{2} \mathrm{O} ; 150 \mathrm{mmol} \mathrm{L}-1 \mathrm{KCl} ; 0.1 \mathrm{~mol} \mathrm{~L}^{-} 1 \mathrm{H}_{2} \mathrm{NC}\left(\mathrm{CH}_{2} \mathrm{OH}\right)_{3} \\
\text { (TRIS);0.05 mg mL}-1 \mathrm{NaF} \text {. }\end{array}$ \\
\hline \multirow{3}{*}{$\mathbf{E R O}+\mathbf{A B R}$} & $\begin{array}{l}\text { E-FD } \\
\text { D-FD }\end{array}$ & $\begin{array}{l}\text { Oral-B }{ }^{\circledR} \text { Complete (Procter \& } \\
\text { Gamble do Brasil, } \\
\text { Queimados, RJ, Brazil) }\end{array}$ & $\begin{array}{l}\text { Hydrated silica, Sodium fluoride ( } 1100 \mathrm{ppm} \text { F). Sorbitol, } \\
\text { aqua, disodium pyrophosphate, aroma, sodium lauryl } \\
\text { sulfate, sodium hydroxide, alcohol, xanthan gum, sodium } \\
\text { saccharin, polyethylene, glycerin, carbomer, poloxamer } \\
407 \text {, titanium dioxide, mica, limonene, cinnamal, blue } 1 \\
\text { lake, yellow } 10 \text { lake, polysorbate } 80 \text {, iron oxides, sodium } \\
\text { benzoate, cetylpyridinium chloride, yellow 5, benzoic } \\
\text { acid. }\end{array}$ \\
\hline & $\begin{array}{l}\text { E-AR } \\
\text { D-AR }\end{array}$ & $\begin{array}{l}\text { Colgate }{ }^{\circledR} \text { Sensitive Pro-Relief } \\
\text { (Colgate-Palmolive, São } \\
\text { Bernardo do Campo, SP, } \\
\text { Brazil) }\end{array}$ & $\begin{array}{l}\text { Arginine } 8 \% \text {, Calcium carbonate, } \\
\text { monofluorophosphate }(1450 \mathrm{ppm} \text { F). Aqua, sorbitol, } \\
\text { bicarbonate, sodium lauryl sulfate, aroma, sodium } \\
\text { silicate, cellulose gum, sodium bicarbonate, titanium } \\
\text { ioxide, potassium acesulfame, xanthan gum, sucralose. }\end{array}$ \\
\hline & $\begin{array}{l}\text { E-CS } \\
\text { D-CS }\end{array}$ & $\begin{array}{l}\text { Regenerate }{ }^{\circledR} \text { Enamel Science } \\
\text { Advanced } \quad \text { toothpaste } \\
\text { (Unilever, Le Meux, France) }\end{array}$ & $\begin{array}{l}\text { Calcium silicate, Sodium monofluorophosphate (1450 } \\
\text { ppm F). Glycerin, PEG-8, hydrated silica, trisodium } \\
\text { phosphate, sodium phosphate, Aqua, PEG-60, sodium } \\
\text { lauryl sulfate, aroma/flavor, synthetic fluorphlogopite, } \\
\text { sodium saccharin, polyacrylic acid, tin oxide, CI77891, } \\
\text { limonene. }\end{array}$ \\
\hline
\end{tabular}

Legend: ERO - erosion; ERO + ABR - erosion plus abrasion; E - enamel; D - dentin; AS - artificial saliva; FD - fluoridated dentifrice; AR - arginine; CS - calcium silicate. Source: Authors.

In Table 1 it is important to observe the composition of each toothpaste as well as the fluoride concentration to later better understand the results.

\section{$2.3 \mu$-EDXRF measurements}

The evaluation of the inorganic content of specimens was performed before $\left(1^{\text {st }}\right)$ and after treatments $\left(2^{\text {nd }}\right)$. The baseline inorganic composition $(\mathrm{Ca}$ and $\mathrm{P}$ weight percentages, wt \%) of samples were evaluated by surface line mappings $(\mathrm{n}=$ 72) before treatments for samples selection $\left(1^{\text {st }}\right)$. The inorganic composition of enamel and dentin specimens were previously measured by micro energy-dispersive X-ray fluorescence spectrometry ( $\mu$-EDXRF, model $\mu$-EDX 1300, Shimadzu, Kyoto, Japan), to standardize the samples selected for the study (Table 1), as previously reported (Gomes et al., 2017). The line maps covered a central line of $300 \times 1$ points (steps of $20 \mu \mathrm{m}, 10 \mathrm{~s}$ per point, $15 \mathrm{kV}$ ). Statistical analysis of the results of this $1^{\text {st }}$ analyses was performed by the Tukey-Kramer multiple comparison test using GraphPad Prism (GraphPad Software, San Diego CA, USA).

To select the 72 samples with more homogeneous inorganic content, eight specimens that had values below or above the average of the Ca wt\% (enamel: $35.2 \pm 1.8 \%$; dentin: $22.4 \pm 0.9 \%$ ) were excluded (Raimundo Nonato Silva Gomes et al., 2018). After that, root dentin and enamel specimens were randomly allocated in eight groups $(\mathrm{n}=72)$ of 9 samples $($ Table 1$)$. After treatments, the $\mu$-EDXRF measurements $\left(2^{\text {nd }}\right)$ were performed using the same parameters $(n=72)$.

After treatments, elemental distribution area maps $(n=8)$ were obtained for a representative specimen of each group (enamel and dentin). The parameters used were as follows: area, $40 \times 30$ points; steps, $20 \mu \mathrm{m}$; voltage, $15 \mathrm{kV}$; incident beam diameter, $50 \mu \mathrm{m}$. After mapping, the data were processed using Shimadzu micro EDX MP ver. 1.03 (Shimadzu) and the resulted images composed a representative distribution of $\mathrm{Ca}$ and $\mathrm{P}$ elements throughout a selected area of the samples. Chemical images of saliva treated groups were used as control.

The degree of protection against demineralization produced by the fluoride and laser treatments was estimated based on the differences between mineral treated content (MTC) (Ca or P) and baseline content (MBC) (as represented by the control 
group) (Soares et al., 2018; Soares et al., 2019). The mineral variation (MV) was expressed as the percentage difference between the data collected before and after treatment, as follows:

$M V \%=\frac{\lfloor(M T C-M B C)\rfloor}{M B C} \times 100$

\subsection{Erosion and abrasion cycles}

Samples from the control group were subjected to erosion in orange juice (ERO) followed by remineralization treatment with artificial saliva without the brushing process (Table 1) to characterize the erosive effect isolated, without the abrasion effect caused by brushing. Samples from the groups of tested dentifrices were subjected to abrasion (ABR) in the intervals of the demineralization-remineralization cycles (ERO) (Table 1).

One complete demineralization-remineralization cycle consisted of immersing the sample in a sealed container with 3 $\mathrm{ml}$ of orange juice (Del Vale Laranja Caseira, Leão Alimentos e Bebidas Ltda., Linhares, ES, Brazil, pH 3.5), agitating with a magnetic shaker (C-MAG HS 7 IKAMAG, SOVEREIGN, São Paulo, SP, Brazil) for 10 minutes and $37^{\circ} \mathrm{C}$. The specimens were then rinsed with tap water for $30 \mathrm{~s}$ and immersed in $3 \mathrm{ml}$ of artificial saliva for 60 minutes and $37^{\circ} \mathrm{C}$. These procedures were performed three times daily for five days.

Groups FD, AR and CS also underwent the same erosive (ERO) cycle of group AS. However, after each erosion step, the samples were subjected to the simulated brushing process (ERO + ABR). The brushed samples were immersed in saliva at each stage of erosion. After the simulated brushing, a new cycle of demineralization-remineralization was carried out, where remineralization was performed by immersion in saliva for 60 minutes at each cycle.

For a controlled abrasion by simulated brushing, samples were mounted individually in acrylic base placed in an automatic brushing machine (MSEt, $1500 \mathrm{~W}$, Marcelo Nucci ME, São Carlos, SP, Brazil) and subjected to 150 cycles of the abrasive challenge under a 200-g load at 4.5 movements per second and $37 \pm 0.5^{\circ} \mathrm{C}$. The samples were brushed with a soft brush using the respective dentifrices of each group (Table 1) diluted in distilled water in the proportion 1: 3 by weight, thus reproducing the dilution that occurs by the saliva (Passos et al., 2013). The samples were stored overnight in artificial saliva at $37^{\circ} \mathrm{C}$ (Passos et al., 2013).

\subsection{Determination of surface roughness (Ra)}

A surface roughness tester (TR200, Qualitest International Inc., Ft. Lauderdale, FL, USA) was used to measure the average surface roughness (Ra) operating with a stylus contacting the specimen surface. Surface roughness was measured for each specimen with a $4 \mathrm{~mm}$ diamond stylus, $90^{\circ}$ reading angle, $0.25 \mathrm{~mm}$ cutoff length, and a trace length of $1.25 \mathrm{~mm}$ (Soares \& De Carvalho Filho, 2015). Tracings were performed in triplicate for each specimen. The average value of tracings for each specimen were calculated as the Ra measure. Then the average of nine Ra values per group was calculated (Soares et al., 2018; Soares \& De Carvalho Filho, 2015).

\subsection{Scanning electron microscopy (SEM) analyses}

After treatments, the enamel $(\mathrm{N}=4)$ and dentin $(\mathrm{N}=4)$ samples were investigated by SEM. The samples were dehydrated using a graded series of ethanol $(50 \%, 70 \%, 90 \%$, and 100\%) for $10 \mathrm{~min}$ at each step. After that, the samples received a thin layer of gold $(10 \mathrm{~nm})$ and were examined using a scanning electron microscope (SEM, EVO-MA10, Carl ZeissVR STM, Oberkochen, BW, Germany) with an acceleration voltage of $20 \mathrm{kV}$ (Nahorny et al., 2017). 


\subsection{Statistical analyses}

The $\mathrm{Ca}$ and $\mathrm{P}$ weight percentages (wt \%), the $\mathrm{Ca} / \mathrm{P}$ molar ratio and $\mathrm{Ra}$ values were statistically analyzed using GraphPad Prism (version 5.01 for Windows, GraphPad Software, San Diego California USA). All statistical comparisons were performed with a significance level of $\alpha=0.05$ (95\% confidence intervals). A one-way ANOVA with Dunnett's post-test was performed to compare the control and other treatments. Bonferroni's multiple comparison test was used to evaluate significant statistical differences among the brushed groups (not including the control).

\section{Results}

\section{1 $\mu$-EDXRF surface line mapping}

The results of the $\mu$-EDXRF measurements after treatments are summarized in Figures 1-3. Figure 1 and 2 shows the statistical comparisons between control (AS) and treatment groups (FD, AR and CS) and statistical comparisons between the fluoridated dentifrice (FD) and dentifrices with active compounds (AR and CS) for enamel and dentin, respectively.

Figure 1. Enamel $\mu$-EDXRF results.
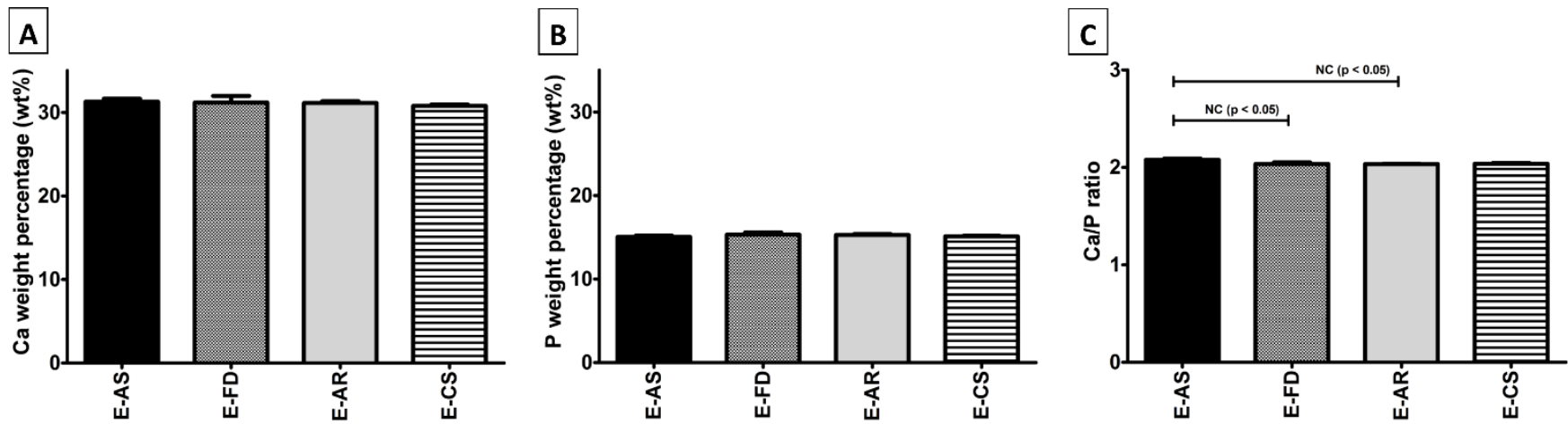

Mean and standard deviations $(\mathrm{n}=9)$ of the average calcium $(\mathrm{A})$, phosphorus weight percentage $($ wt $\%)(\mathrm{B})$, and $\mathrm{Ca} / \mathrm{P}$ molar ratio $(\mathrm{C})$ in the enamel obtained by $\mu$-EDXRF after the treatments. Statistical comparisons (Dunnett's multiple comparison test) were performed between the control (artificial saliva) and treatment groups (capped line at the top). Legend: E - enamel; AS - artificial saliva; FD - fluoridated dentifrice; AR - arginine; CS - calcium silicate. Source: Authors.

Figure 1 describes the effect of treatments in the enamel mineral content with statistical significance. The mean (standard deviation) Ca/P molar ratio values for enamel were E-AS, 1.623 (0.032); E-FD, 1.589 (0.013); E-AR, 1.589 (0.013); and E-CS, 1.592 (0.019). The Ca/P molar ratio was significantly higher in E-AS than in E-FD and E-AR (p < 0.05, Fig. 1C). 


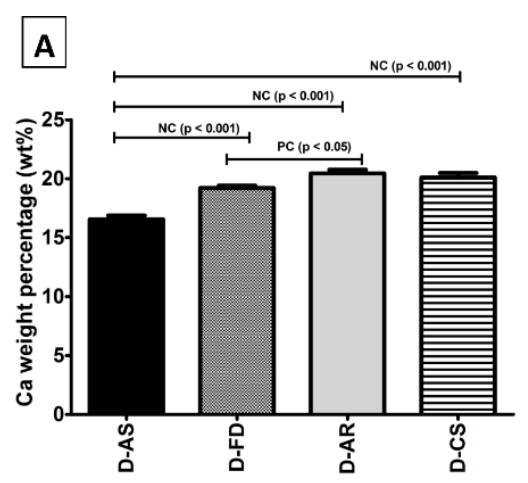

Figure 2. Dentin $\mu$-EDXRF results.
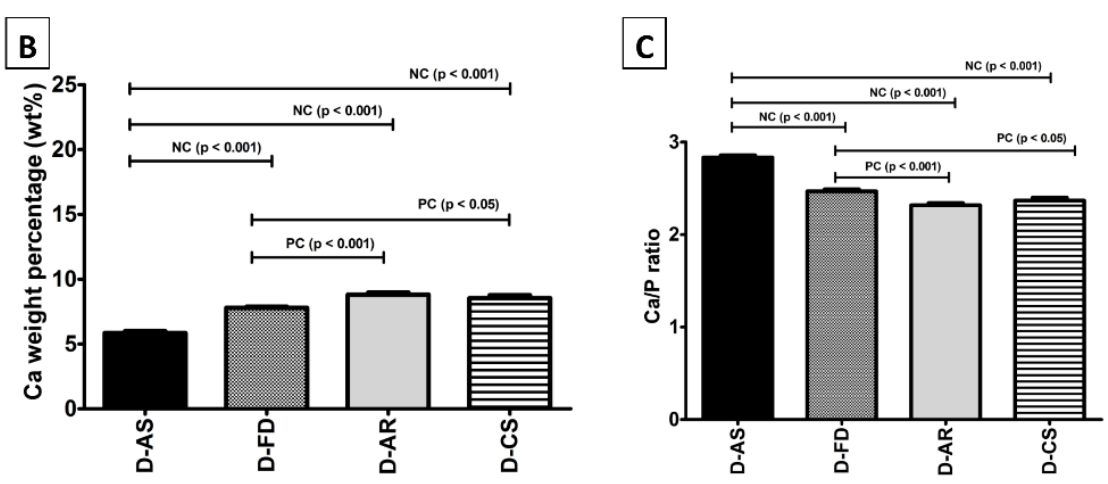

Mean and standard deviations $(\mathrm{n}=9)$ of the average calcium $(\mathrm{A})$, phosphorus weight percentage (wt \%) $(\mathrm{B})$, and $\mathrm{Ca} / \mathrm{P}$ molar ratio $(\mathrm{C})$ in the dentin obtained by $\mu$-EDXRF after the treatments. Statistical comparisons (Dunnett's multiple comparison test) were performed: between the control (artificial saliva) and treatment groups (capped line at the top); between the fluoridated dentifrice and dentifrices with active compounds (Bonferroni's multiple comparison test, capped lines at the bottom). Legend: D - dentin; C - control; AS - artificial saliva; FD fluoridated dentifrice; AR - arginine; CS - calcium silicate. Source: Authors.

Figure 2 describes the effect of treatments in the dentin mineral content with statistical significance. Considering the dentin substrate, the $\mathrm{Ca}$ and $\mathrm{P}$ weight percentages were significantly lower for the control group (D-AS) than in the brushed groups ( $\mathrm{p}<0.001$, Figure 2A, B). The mean (standard deviation) $\mathrm{Ca} / \mathrm{P}$ molar ratio values for dentin were D-AS, $2.211(0.060)$; D-FD, 1.810 (0.056); D-AR, 1.928 (0.051); and D-CS, 1.851 (0.072). The Ca/P molar ratio was significantly higher in control than in brushed groups $(\mathrm{p}<0.001$, Figure $2 \mathrm{C}$ ). Among brushed groups, the Ca weight percentage was significantly lower in DFD than in D-AR $(p<0.05$, Figure $2 A)$. The $P$ weight percentage was significantly lower in D-FD than in D-AR ( $<0.001$, Figure $2 \mathrm{~B})$ and $\mathrm{D}-\mathrm{CS}(\mathrm{p}<0.05$, Figure $2 \mathrm{~B})$. The $\mathrm{Ca} / \mathrm{P}$ molar ratio was significantly higher in $\mathrm{D}-\mathrm{FD}$ than in $\mathrm{D}-\mathrm{AR}(\mathrm{p}<0.001$, Figure 2B) and D-CS $(p<0.05$, Figure 2B). 
Figure 3. Enamel and dentin mineral variation (\%) after treatments.

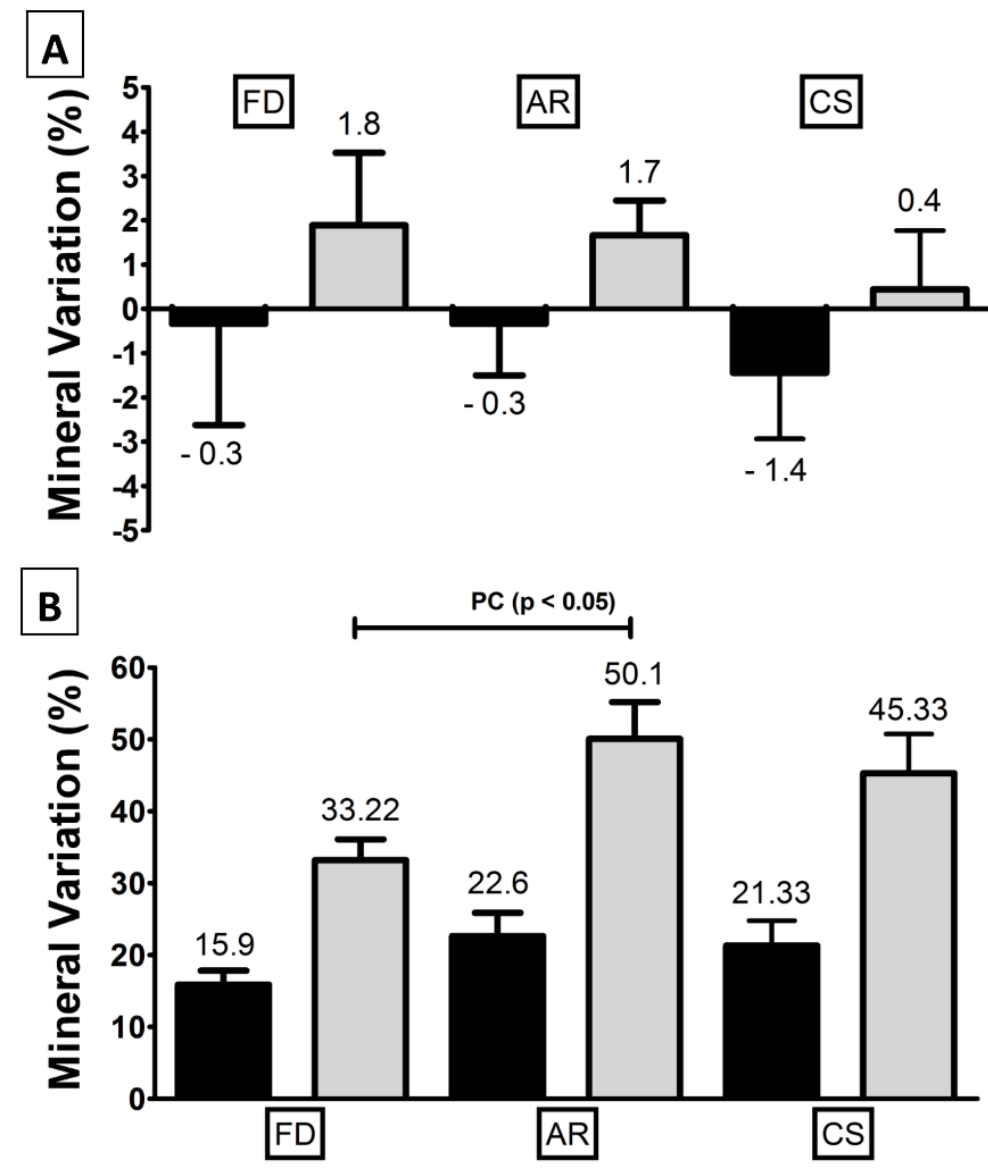

Mineral variation (\%) of the enamel (A) and dentin (B) (calcium - black bars and phosphorus - gray bars) assessed by $\mu$-EDXRF after sample erosion-abrasion in the treatment groups (mineral treated content, MTC) compared to the baseline content (MBC) (as represented by the control group). Statistical comparisons were performed between the fluoridated dentifrice and dentifrices with active compounds (Bonferroni's multiple comparison test, capped lines at the top). Legend: FD - fluoridated dentifrice; AR - arginine; CS - calcium silicate. Source: Authors.

Figure 3 describes the effect of treatments in enamel and dentin mineral variation (MV\%) with statistical significance. Mineral variation was positive for phosphorus element in enamel (Figure 3A). The MV\% for Ca and P content of dentin was positive after brushing (Figure 3B). AR treatment resulted in a significant positive phosphorus variation than in FD ( $\mathrm{p}<0.05$,

Figure 3B).

\section{2 $\mu$-EDXRF surface area mapping}

Figures 4 and 5 show the results of $\mu$-EDXRF microanalysis mapping of enamel and dentin after treatments. Surface area mappings by EDXRF provide the relative concentrations of the elements. A color scale represented the elemental concentrations in the distribution maps: dark blue and white represent minimum and maximum concentration values, respectively, in their component spectrum (Figures 4 and 5). After the erosion in the E-AS (Figures 4A, B) and D-AS groups (control) (Figures 5A, B), significant loss of inorganic content is noted compared to the groups brushed with dentifrices (Figures 4 and $5 \mathrm{C}-\mathrm{H}$ ), as evidenced by the dark blue spots in the images 
Figure 4. $\mu$-EDXRF microanalysis image of enamel groups.
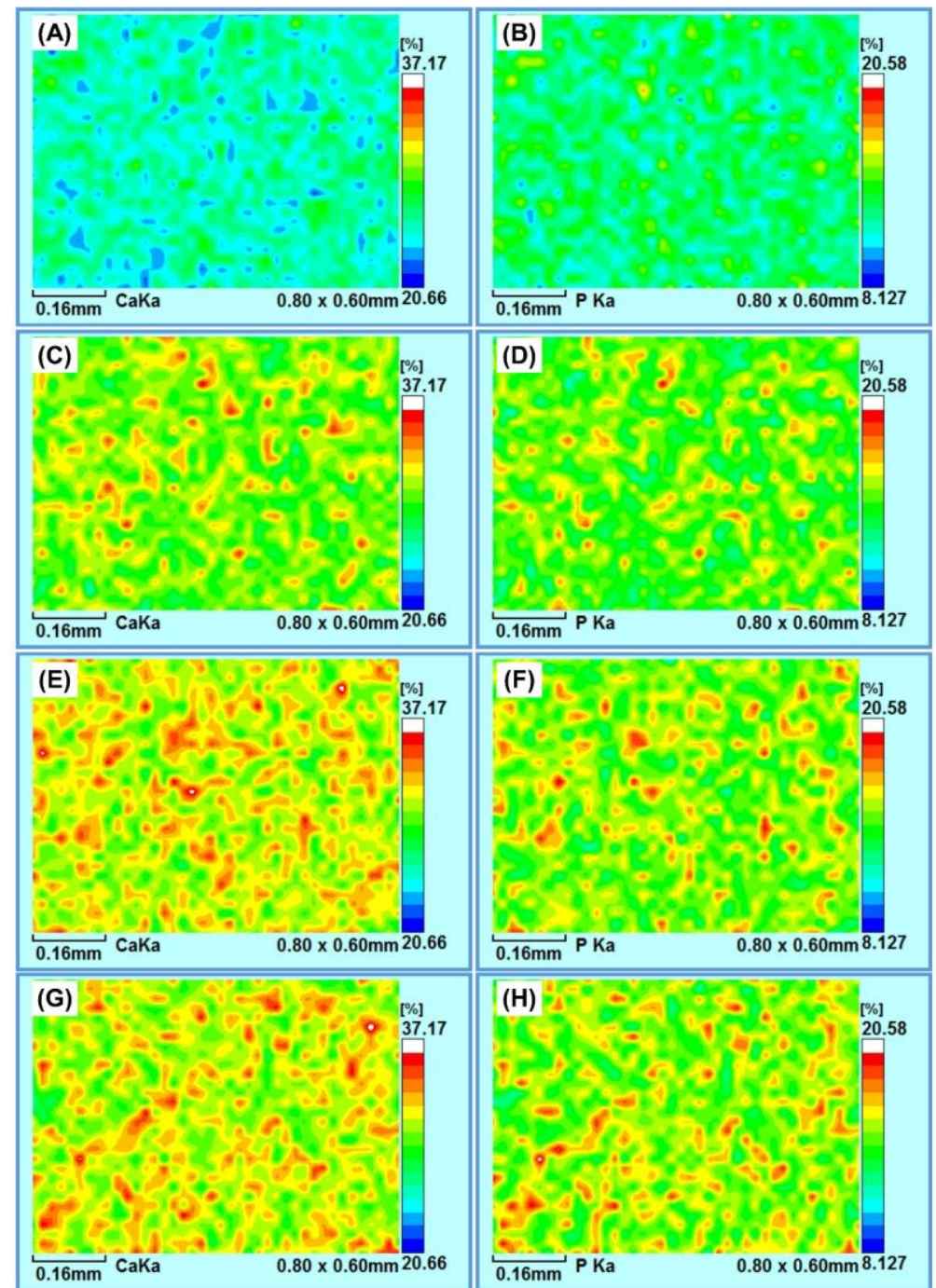

Representative images of $\mathrm{Ca}(\mathrm{A}, \mathrm{C}, \mathrm{E}, \mathrm{G})$ and $\mathrm{P}(\mathrm{B}, \mathrm{D}, \mathrm{F}, \mathrm{H})$ distribution at the enamel surface obtained by $\mu$-EDXRF microanalysis. Treatment with artificial saliva and eroded (control) (A, B), erosion and brushing with FD (C, D), erosion and brushing with AR (E, F) and erosion and brushing with CS $(\mathrm{G}, \mathrm{H})$. The gradient in the intensity of the color scale indicates variations in the inorganic content, such that sites with high mineral contents are shown in red and orange while sites with low mineral contents are shown in cyan and blue. Control group images evidenced reduced mineral content (A, B). Legend: FD - fluoridated dentifrice; AR - arginine; CS - calcium silicate. Source: Authors.

The image provided by the EDXRF analysis in figure 4 shows differences between control and treatments and no differences among treatments. Among the brushed groups, for the enamel samples, no significant differences were observed in the distribution pattern of the inorganic content along the surface (Figures 4C-H). 
Figure 5. $\mu$-EDXRF microanalysis image of dentin groups.

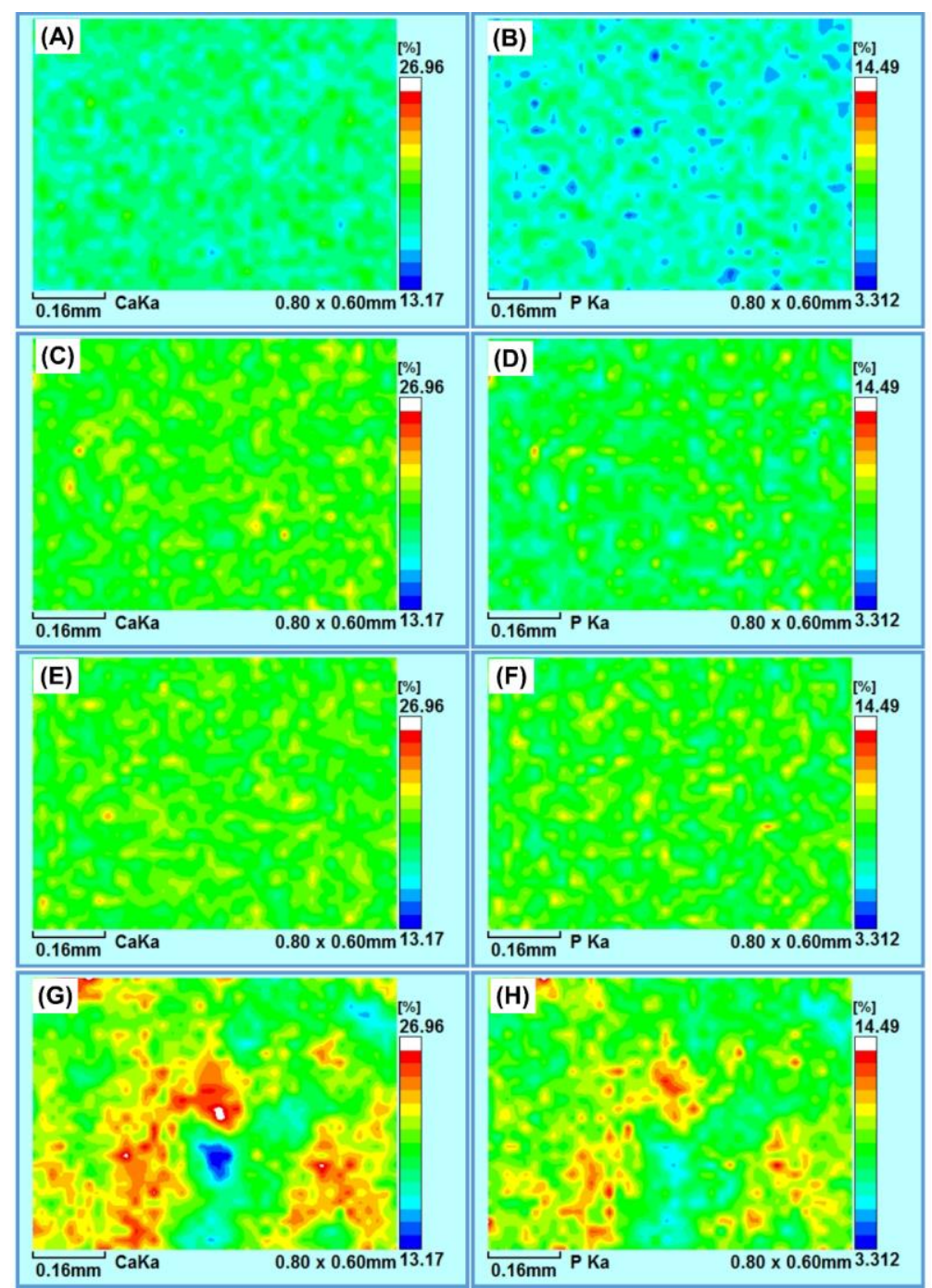

Representative images of $\mathrm{Ca}(\mathrm{A}, \mathrm{C}, \mathrm{E}, \mathrm{G})$ and $\mathrm{P}(\mathrm{B}, \mathrm{D}, \mathrm{F}, \mathrm{H})$ distribution at the dentin surface obtained by $\mu$-EDXRF microanalysis. Treatment with artificial saliva and eroded (control) (A, B), erosion and brushing with FD (C, D), erosion and brushing with AR (E, F) and erosion and brushing with CS $(\mathrm{G}, \mathrm{H})$. The gradient in the intensity of the color scale indicates variations in the inorganic content, such that sites with high mineral contents are shown in red and orange while sites with low mineral contents are shown in cyan and blue. Control group images evidenced reduced mineral content (A, B). Legend: FD - fluoridated dentifrice; AR - arginine; CS - calcium silicate. Source: Authors.

The image provided by the EDXRF analysis in figure 5 shows differences between control and treatments and differences among treatments. In the dentin samples, significant differences in the patterns of chemical distribution of $\mathrm{Ca}$ and $\mathrm{P}$ content throughout the surface can be observed in the group D-CS as noted by the red and yellow spots in the images (Figures 5 G-H). Brushing the dentin with FD dentifrice reduced its phosphorus content, as noted by the cyan spots in the images (Figures $5 \mathrm{D}$ ).

\subsection{Average surface Ra data}

The means and standard deviations of the arithmetic average of $\mathrm{Ra}(\mu \mathrm{m})$ in enamel for each group after erosiveabrasive challenge were E-AS $=0.20(0.04)$; E-AR $=0.18(0.04)$; E-FD $=0.15(0.03)$; and E-CS $=0.18(0.05)$ (Figure 6A). Considering the dentin samples, the average of Ra were D-AS = 0.31 (0.03); D-AR = 0.37 (0.04); D-FD = $0.30(0.04)$; and D$\mathrm{CS}=0.44$ (0.18) (Figure 6B). 
Figure 6. Enamel and dentin surface roughness after treatments.
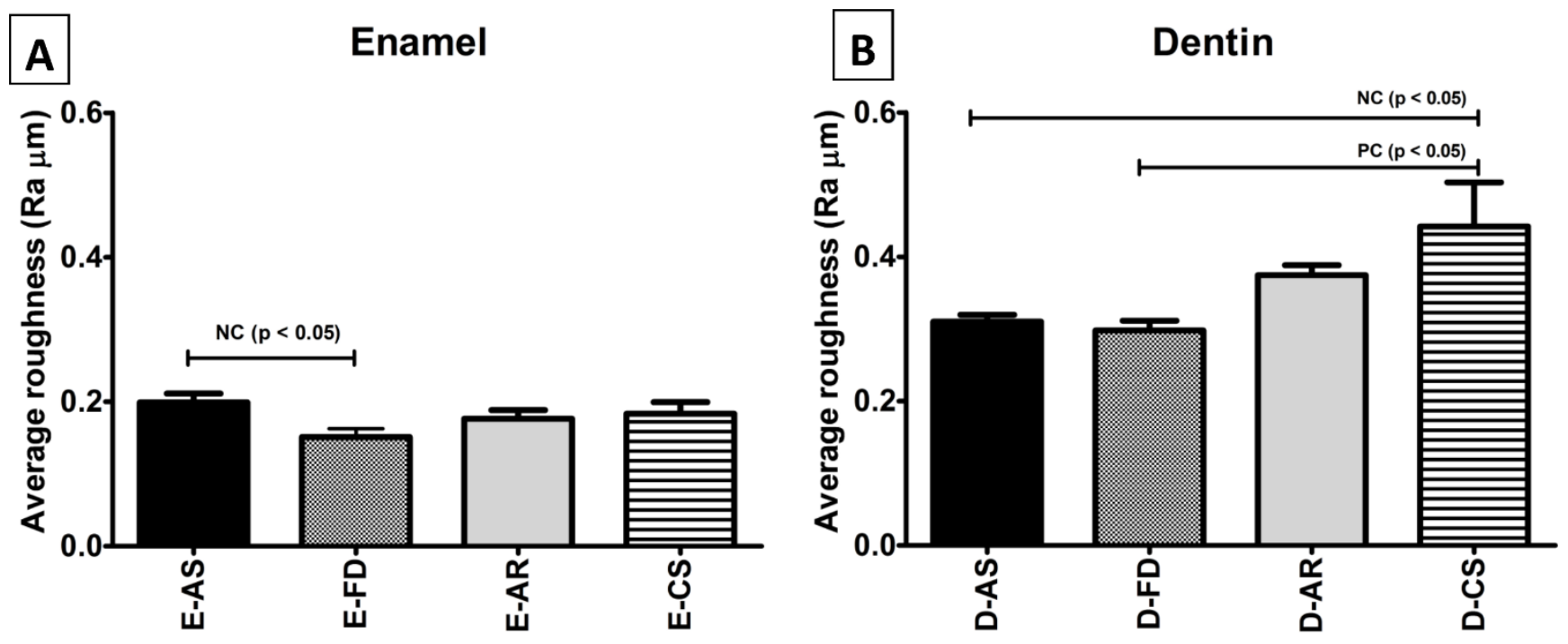

Mean and standard deviation ( $n=9)$ of the surface roughness $(\mathrm{Ra}, \mu \mathrm{m})$ of enamel (A) and dentin (B) specimens after treatments. The capped lines at the top indicate significant statistical comparisons between the control (artificial saliva) and treatment groups (Dunnett's multiple comparison test). The capped lines at the bottom indicate significant statistical comparisons between the fluoridated dentifrice and dentifrices with active compounds (Bonferroni's multiple comparison test). Legend: E - enamel; D - dentin; C - control; AS - artificial saliva; FD fluoridated dentifrice; AR - arginine; CS - calcium silicate. Source: Authors.

Figure 6 represents $\mathrm{Ra}$ results and the significance for each substrate. The Ra values were statistically significantly lower after E-FD $(\mathrm{p}<0.05)$ and statistically significantly higher after D-CS $(\mathrm{p}<0.05)$ as compared to E-AS and D-AS, respectively (control, Figure 6A and B). The D-CS treatment resulted in Ra values statistically significantly higher compared to the D-FD ( $\mathrm{p}<0.05$, Figure $6 \mathrm{~B})$.

\subsection{SEM analysis}

Figures 7 and 8 shows a typical SEM image obtained from the surface of an enamel (Figure 7) and dentin (Figure 8) at two different magnifications (1000 and 10,000×). Morphological differences between groups considering the deposited layer for both enamel and dentin are observed, particularly in surface coverage (Figures 7 and 8). 
Figure 7. SEM analysis of enamel surface.
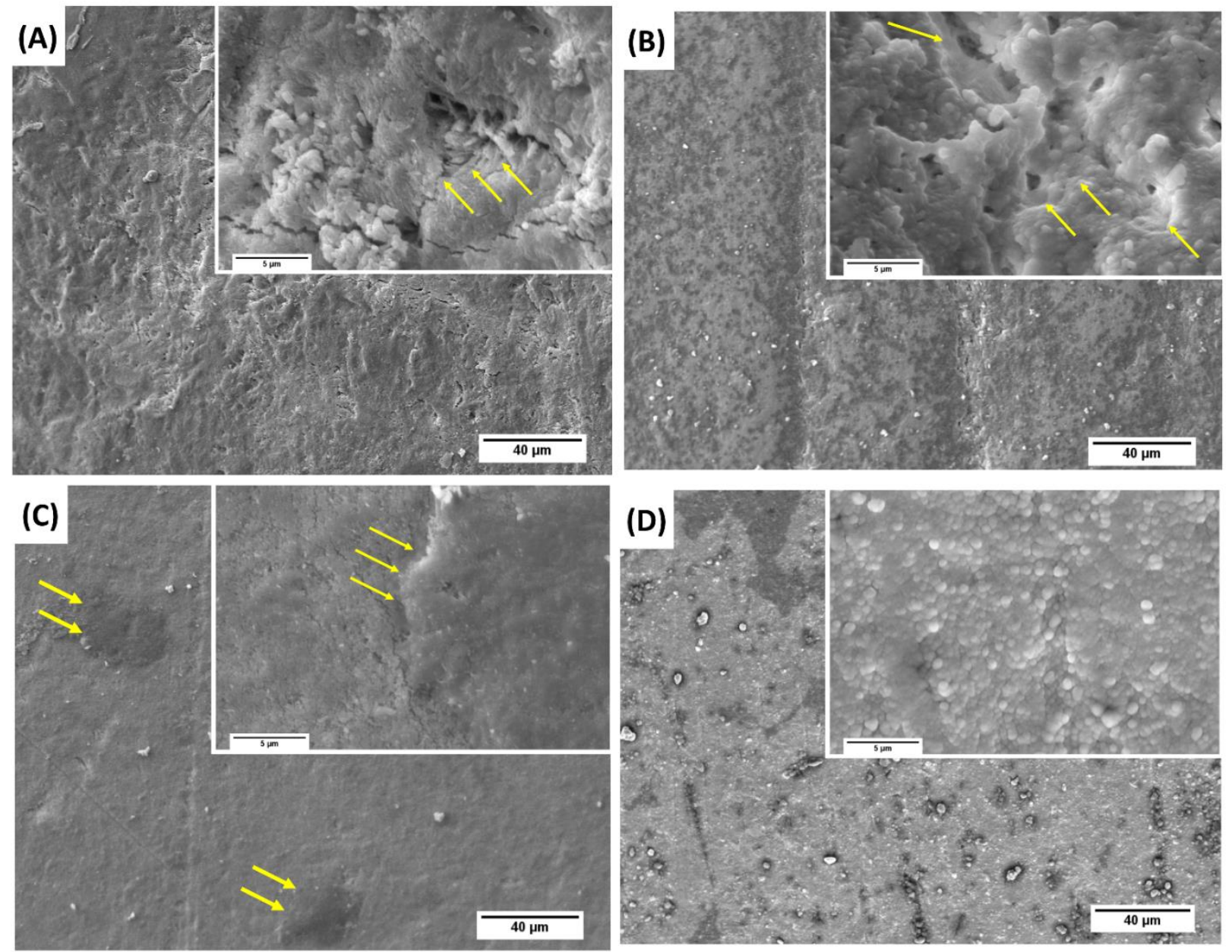

Representative SEM micrographs (1000×) of enamel surface treated with artificial saliva and eroded (control) (A), erosion and brushing with FD (B), AR (C) and CS (D). After erosion and remineralization cycles, the enamel surface of the control group is significantly eroded (arrows) (A). The enamel surface is partially eroded on the FD group (arrows) (B). On the enamel surface of the AR group, a layer of material covers the surface with some agglomerates (arrows, 10,000×) (C). The CS treatment resulted in a deposition of a globular layer on the enamel surface (D). Insets are observations at higher magnification $(10,000 \times)$. Scale bar: $40 \mu \mathrm{m}$ in $1000 \times$, and $5 \mu \mathrm{m}$ in $10,000 \times$. Legend: FD - fluoridated dentifrice; AR - arginine; CS - calcium silicate. Source: Authors.

After erosion and remineralization cycles, the enamel surface of the control group is significantly eroded (arrows) (Figure 7A). The enamel surface is partially eroded on the surface of FD group (arrows) (Figure 7B). On the enamel surface of AR group, a layer of material covers the surface with some agglomerates (arrows, Figure 7C). The CS treatment resulted in a deposition of a globular layer on the enamel surface (Figure 7D). 
Figure 8. SEM analysis of dentin surface.
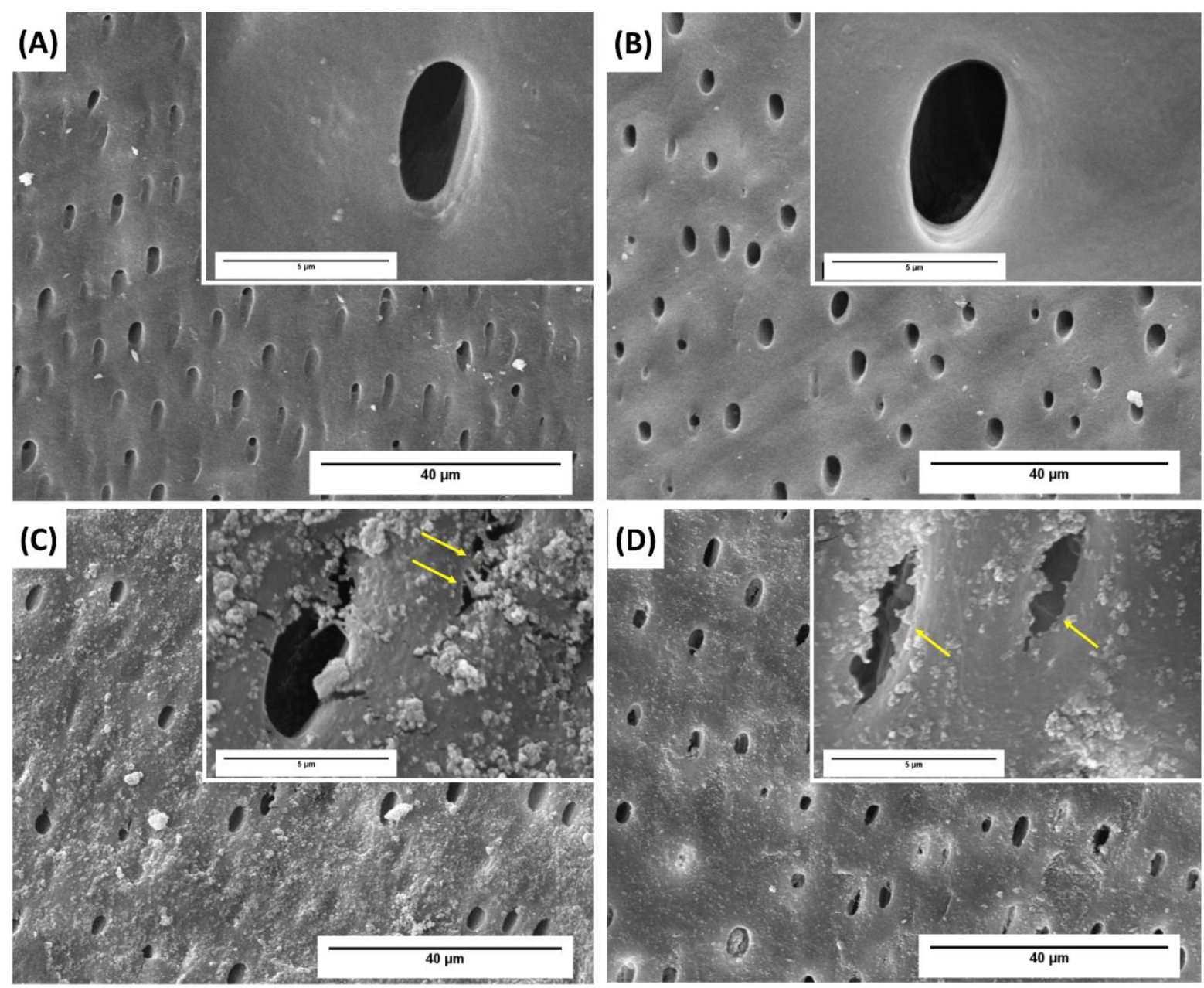

Representative SEM micrographs $(1000 \times)$ of dentin surface treated with artificial saliva and eroded (control) (A), erosion and brushing with FD (B), AR (C) and CS (D). After erosion and remineralization cycles, the dentin surface of the control group is eroded with partially opened tubules (A). The dentin surface shows opened tubules on the surface of the FD group (B). On the dentin surface of the AR group, a granular layer of deposits covers the surface with some occluded tubules (arrows, 10,000×) (C). The CS treatment resulted in a partial deposition of a granular layer on the dentin surface with tubules partially occluded (arrows, 10,000×) (D). Insets are observations at higher magnification (10,000×). Scale bar: $40 \mu \mathrm{m}$ in $1000 \times$, and $5 \mu \mathrm{m}$ in 10,000×. Legend: FD - fluoridated dentifrice; AR - arginine; CS - calcium silicate. Source: Authors.

After erosion and remineralization cycles, the dentin surface of the control group is eroded with partially opened tubules (Figure 8A). The dentin surface shows opened tubules on the surface of the positive control group (Figure 8B). On the dentin surface of AR group, a granular layer of deposits covers the surface with some occluded tubules (arrows, Figure 8C). The CS treatment resulted in a partial deposition of a granular layer on the dentin surface with tubules partially occluded (arrows, Figure 8D). 
Figure 9. Detailed SEM view of dentin treated with AR and CS dentifrices.
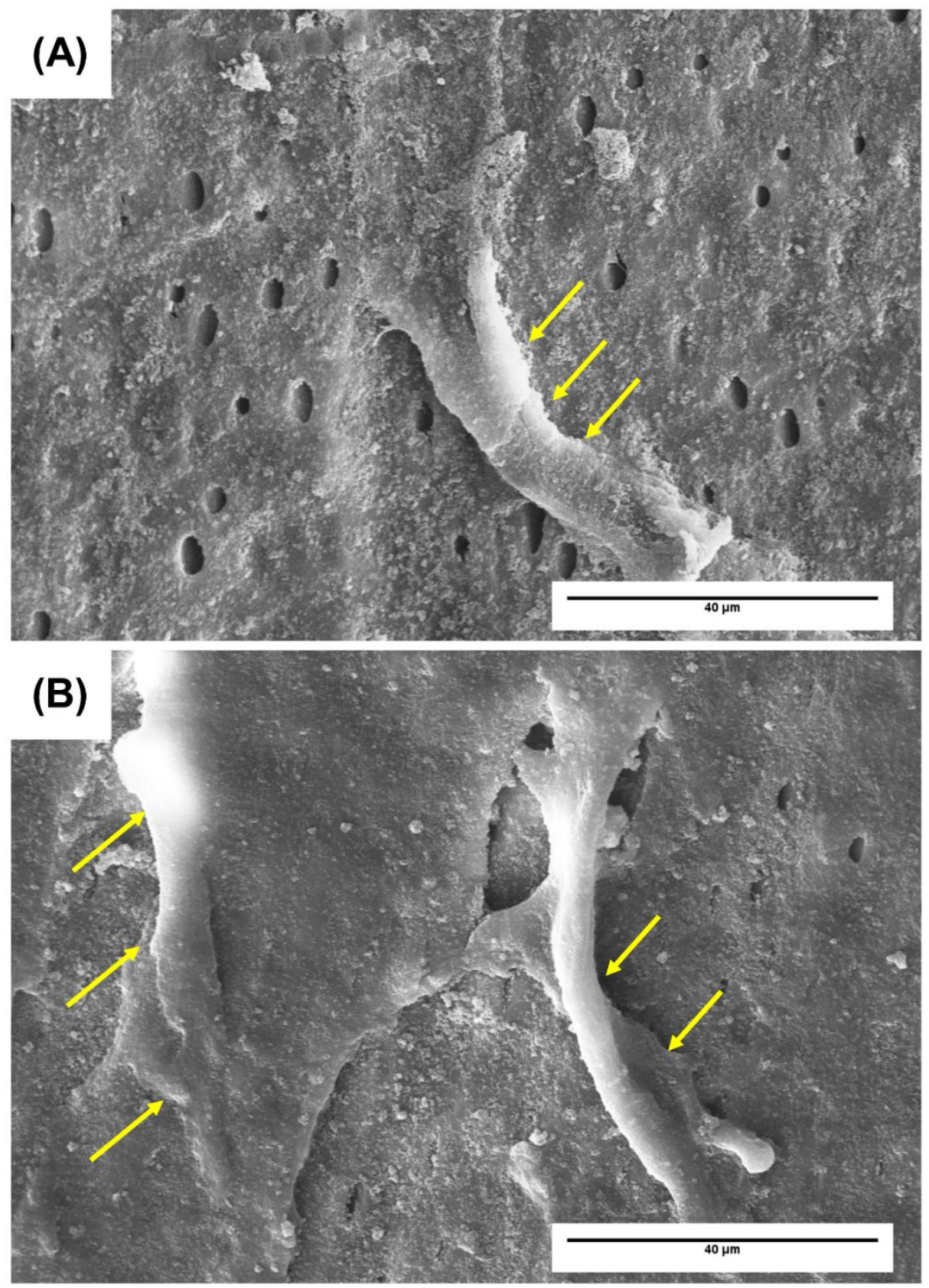

Representative SEM micrographs (1000×) of dentin surface subjected to erosion and brushing with AR (A) and CS (B). After erosion and remineralization cycles, the dentin surface of the AR group, a granular layer of deposits covers the surface with some occluded tubules and sites with a concentration of deposits as barriers (arrows) (A). The CS treatment resulted in occluded tubules and larger sites of barrier deposits (arrows) (B) than in the AR group. Scale bar: $40 \mu \mathrm{m}$. Legend: AR - arginine; CS - calcium silicate. Source: Authors.

Figure 9 illustrates a view of the dentin surface of groups treated with AR and CS dentifrices and complement figure 8 showing sites of deposits forming barriers (Figure9, arrows) with greater covering in CS (Figure 9B) than in AR (Figure 9A).

\section{Discussion}

Today, patients used, as a daily hygiene measure, dentifrices to protect the teeth against caries and to prevent dental erosion. There are many dentifrices options available on the market and, this can be a problem for patients to choose and use the product correctly. 
Fluoride (F) present in dentifrices acts as a preventive-therapeutic agent (Tenuta \& Cury, 2013), and previous studies reported that they must have at least $1.000 \mu \mathrm{g}$ soluble $\mathrm{F} / \mathrm{g}$ to be able to reduce mineral loss during the $\mathrm{pH}$-cycling (Ortiz et al., 2016). Sodium monofluorophosphate (NaMFP) and sodium fluoride (NaF) are the two most common sources of fluoride used in currently marketed fluoride dentifrices (Vogel et al., 2000).

In the present study, a regular dentifrice with low cost and containing reduced $\mathrm{F}$ content was selected. The purpose was to simulate a limited protection condition to the patients, which can occur clinically using conventional dentifrices containing $1.000 \mathrm{ppm}$ of fluoride. The reason for using this fluoride concentration is that the regular use of fluoridated dentifrices (FD) containing at least 1.000 ppm of soluble fluoride decreases dental caries prevalence and severity worldwide (Sanchez et al., 2018; Walsh et al., 2010).

Also, we evaluated two types of active compounds contained in a dentifrice. These two brands of dentifrices were selected because they are available for sale in pharmacies and supermarkets and because they bring active compounds recently presented as effective in dental protection (Crastechini et al., 2019; João-Souza et al., 2019; Lombardini et al., 2014; Olley et al., 2012; Poggio et al., 2014; Sanchez et al., 2018; Sullivan et al., 2014; Sun et al., 2014; Wood et al., 2018).

With this type of comparison, the present study applied analytical tools to evaluate the performance of dentifrices with different concentrations of fluoride and types of fluoride release mechanism: NaMFP and NaF. These differences should be taken into consideration when interpreting the results. It is relevant to mention that the degree of protection obtained by dentifrices is related to the fluoride concentration and release mechanism. The fact that artificial saliva was used instead of human saliva implies that the MFP hydrolysis probably occurred in the demineralization solution and not artificial saliva.

It is known that $\mathrm{NaF}$ does not require a hydrolysis step to release fluoride, thus, in a clinical situation, larger amounts of such labile fluoride sources as $\mathrm{CaF}_{2}$ or cellular cation-bound fluoride may form in plaque, salivary precipitates and oral mucosa (Vogel et al., 2000). Considering the dentifrices containing NaMFP, the advantages of its mechanism are the fact that occurs a specific effect of the MFP ion to reduce enamel solubility and a synergistic effect of the MFP ion with calcium and phosphate (Vogel et al., 2000).

Differences in the composition and active ingredients may result in different levels of protection (Faller, Eversole, \& Tzeghai, 2011). The constant evolution and research in the dentifrices field resulted in a new dentifrice containing calcium silicate, sodium phosphate, and fluoride (Ionta et al., 2019). The manufacturer proposed that this dentifrice could be used with the proposal to regenerate the enamel lost due to erosive acids.

Previous studies evaluated the effect of the calcium silicate dentifrice on teeth and reported different results (Ionta et al., 2019; Joiner et al., 2014; Parker et al., 2014; Sun et al., 2014; Wood et al., 2018). This formulation of dentifrice represents a new option of enamel protection. However, caution has to be taken when extrapolating these results to clinical conditions.

Arginine based dentifrices were also introduced as a possibility to protect teeth against erosion and caries (Aguiar et al., 2017; Oliveira et al., 2019; West et al., 2017). Despite the positive results obtained with arginine addition, stannous fluoride $(\mathrm{SnF} 2)$ based dentifrices showed superiority for protecting human teeth against the initiation and progression of dental erosion (West et al., 2017).

The chemical, mechanical and morphological analysis performed indicated that, under the experimental conditions, the enamel and dentin eroded and brushed with dentifrices (ERO + ABR), showed significant differences in those features when compared to that found in the control group, which was only subjected to erosion (ERO). The differences found in the chemical composition (Figures 1-5) and the abrasion pattern between enamel and dentin (Figures 7-9) are related to the chemical composition and morphological structure of both substrates and differences in toothpaste composition.

The significant changes in $\mathrm{Ca} / \mathrm{P}$ molar ratio of unprotected enamel after abrasion (E-AS, control group) in comparison to the other treatments (E-FD and E-AR) $(p<0.05$, Figure $1 C)$ is a result of the relevant chemical dissolution of enamel 
inorganic components by the acids contained in the orange juice (citric acid) and its $\mathrm{pH}(\sim 3.5)$. SEM micrographs confirmed this result, showing a significant eroded surface in group E-AS with greater porosities in enamel than in the other treatments (Figure 7A). Previously, our group describe the same surface features, where the SEM analysis revealed a nonuniform loss of enamel structure and the presence of craters and surface irregularities at multiple points after erosion by orange juice (Soares et al., 2018).

Dentin showed more relevant chemical and morphological changes after erosion-brushing than in enamel samples (Figures 1-9). Those changes are a result of differences in chemical composition and morphological features of both substrates. Enamel is a highly mineralized tissue, with the inorganic portion being predominant ( $96 \%$ nonstoichiometric form of hydroxyapatite). A tubular structure forms the dentin architecture, which contains more organic material (collagen) and is more soluble than enamel (Gomes et al., 2019; Lussi et al., 2011; Shellis et al., 2010).

Gomes et al. (2019) reported morphological and chemical differences between enamel and dentin brushed with a conventional fluoridated dentifrice after chemical erosion by acidic medicaments, showing a severe inorganic material loss in dentin after abrasion by brushing in a compromised substrate. The study suggested that brushing adds to the erosion caused by respiratory medicaments and that fluoridation by a conventional dentifrice has a very limited protective role. However, in the present study, two dentifrices contained active compounds were tested (arginine and calcium silicate) with positives results in terms of enamel and dentin protection.

The present study suggests that brushing with dentifrices containing active compounds had a positive effect on enamel features and composition. However, in the control group (without brushing), a reduced protective effect was obtained. The $\mu$ EDXRF area mapping images also highlighted the difference in the contents between enamel and dentin and among groups (Figures 4 and 5).

SEM micrographs revealed a very compact, thick and uniform surface layer on enamel brushed with AR dentifrice (Figure 7C) in comparison to the control and FD dentifrice (Figure 7A, B). This layer remained after erosive cycles with orange juice. Our results are in agreement with the study of Lombardini et al. (2014), which showed that Colgate Sensitive Pro Relief promoted enamel remineralization, thus preventing the erosion produced by a soft drink (Coca Cola). In contrast, the enamel without brushing showed significant exposure of enamel deep layers, with craters and porosities (Figure 7A), and the enamel brushed with a conventional dentifrice showed an intermediary level of porosities (Figure 7B), demonstrating thus the importance of using effective hygiene products in the daily routine. The enamel brushed with a dentifrice containing calcium silicate resulted in a deposition of a globular layer on the enamel surface which seems to protect the enamel during the erosive cycles (Figure 7D).

Previous studies explained that the mechanism of action of this dentifrice for repair and protection of enamel is derived from the deposition of hydroxyapatite (Crastechini et al., 2019; Parker et al., 2014; Sun et al., 2014). Besides that, the fluoride present in this dentifrice promoted the formation of calcium fluoride deposits on the enamel surface (Crastechini et al., 2019; Featherstone et al., 1982). Oliveira et al. (2019) study showed that arginine-based dentifrices increase the microhardness of sound and demineralized bovine enamel surfaces and reported that the mechanism involved was the presence of free calcium ions in the oral environment make the saliva super-saturated and favor remineralization, despite the negative charge in demineralized hydroxyapatite crystals.

In the present study, it seems that the presence of a more homogeneous and thicker layer of deposits found in E-CS as illustrated by SEM micrographs (Figure 7D) compared to E-AR treatment (Figure 7C) resulted in the significant differences found in the $\mathrm{Ca} / \mathrm{P}$ molar ratio between control and the AR dentifrice (Figure 1C). Considering the E-FD group, the significant difference in $\mathrm{Ca} / \mathrm{P}$ molar ratio regarding the $\mathrm{E}-\mathrm{AS}$ group was probably due to the absence of a deposits layer, as shown by SEM micrographs (Figure 7B). The most effective treatment in enamel resulted in a thicker and homogeneous layer of deposits 
covering the surface. When the incident $\mathrm{x}$-rays interact with the surface, a smaller amount of $\mathrm{x}$-rays pass through this thicker layer, resulting in smaller amounts of backscattered x-rays. As a consequence, reduced calcium and phosphorus weight percentages were found. Thus the $\mathrm{Ca} / \mathrm{P}$ molar ratio was higher than in the other two dentifrices (without significance) when compared to the positive control (Fig 1C).

The erosion in dentin specimens without brushing with dentifrices resulted in a significant loss of calcium and phosphorus element and a higher $\mathrm{Ca} / \mathrm{P}$ molar ratio than in brushed groups (Figure 2). This result indicates that brushing the exposed dentin areas with a fluoridated dentifrice containing at least 1100ppm of fluoride helps protect the substrate from loss of minerals and dental structure. However, the dentifrice without active compounds (D-FD) and low-F content resulted in lower mineral levels ( $\mathrm{Ca}$ and $\mathrm{P}$ ) and higher $\mathrm{Ca} / \mathrm{P}$ molar ratio in dentin than the other dentifrices (D-AR and D-CS) (Figure 2). This result agrees with a previous systematic review study reporting that the regular use of fluoridated dentifrices containing at least $1000 \mathrm{ppm}$ of soluble fluoride is one of the main reasons for the decrease in dental caries prevalence and severity worldwide (Walsh et al., 2019).

These significant changes in the $\mathrm{Ca} / \mathrm{P}$ molar ratio between brushed groups and control and between the $\mathrm{D}$-FD group and the other dentifrices indicated that the original ratio between organic and inorganic components was modified (Figure 2C) (Malkoc et al., 2011; Soares et al., 2013). The practical result of this type of change is that permeability and solubility characteristics of dentin changed (Malkoc et al., 2011; Soares et al., 2013). Such a level of change in the proportion of inorganic and organic components can be observed in surface micrographs obtained by SEM analysis (Figure 8). Opened dentin tubules were found in the dentin of groups D-AS and D-FD (Figures 8A, B). The brushing of dentin with dentifrices containing active compounds (D-AR and D-CS) resulted in the presence of a granular layer of deposits covering the surface (D-AR, Figure 8C) and some occluded tubules (D-CS, Figure 8D). This result agrees with the $\mu$-EDXRF results showing that the inorganic composition of dentin was different from the control and D-FD group, which had lower mineral levels of $\mathrm{Ca}$ and P (Figure 2). Our results agree with Berkathullah, Farook, and Mahmoud (2018) study, where they found high Ca peaks in EDX spectra after treatment with an arginine-based dentifrice, which possibly is due to the formation of calcium-containing precipitates covering almost all the entire dentinal surfaces and occluding dentin tubules.

The visible layer of deposits after dentin brushing with AR dentifrice (Colgate Sensitive Pro-Relief, containing arginine and calcium carbonate) observed in the SEM results of the present study (Figure 8C) is a result of deposition of calcium and phosphate dentin like minerals, which promotes a natural obliteration mechanism of dentin tubules (Berkathullah et al., 2018; Petrou et al., 2009).

The data obtained by roughness complemented the $\mu$-EDXRF and SEM analysis with different results between groups considering enamel or dentin. The group E-FD, which was brushed with a conventional dentifrice, showed statistically significant lower Ra values than in the control group (E-AS) (Figure 6A), and this result was probably due to the absence of a protective layer on enamel after cycles or brushing and erosion (Figure 7B). Considering the dentin substrate (Figure 6B), higher Ra values found in AR and CS groups indicated the deposition of a granular layer covering the surface (Figures 8C, D). The presence of deposits on the dentin surface CS group (Figures $8 \mathrm{D}$ ) indicates a positive effect in the dentin tubule obliteration even after erosion-abrasion episodes. The clinical significance of these results is the possible protection in the case of patients with dentin hypersensitivity.

Complimentary SEM micrographs of AR and CS evidenced deposits forming barriers covering dentin tubules in higher extension in CS than in AR (Figure 9). This result agrees with the roughness data (Figure 6B) and $\mu$-EDXRF chemical images (Figure 5 E-H). João-Souza et al. (2019) study found similar results, where the dentifrice containing calcium silicate and sodium phosphate (Regenerate ${ }^{\circledR}$ ) acts by forming hydroxyapatite, depositing particles of calcium silicate on the dentin surface and covering the opening of the dentinal tubules. 
The limitations of this study are the use of bovine teeth and the impossibility of direct measure of Ca and $\mathrm{P}$ ions release by $\mu$-EDXRF. However, the results are representative since these limitations could be minimized. The bovine teeth have been largely adopted as a substrate for in vitro dental erosion experiments due to its advantages like the facility to obtain in large amounts, among others properties (Ionta et al., 2019; Oliveira et al., 2019; Soares et al., 2018; Soares et al., 2019). The levels of $\mathrm{Ca}$ and $\mathrm{P}$ ions that remain on the surface after treatment and erosion can be determined indirectly by $\mu$-EDXRF (Soares et al., 2018; Soares et al., 2019).

\section{Final Considerations}

Different active compounds resulted in a variable degree of surface covering regarding the type of substrate. Thus, the initial hypothesis that there are significant differences between the dentifrices mode of action regarding the inhibition of enamel and dentin demineralization can be accepted.

Brushing with a dentifrice containing at least $1100 \mathrm{ppm}$ of fluoride is relevant to minimize the erosive effects of acidic foods and drinks. Active compounds like arginine and calcium silicate in dentifrices could improve the protection by the mechanism of deposition of a surface layer like deposits. $\mu$-EDXRF technique combined with SEM was viable to perform a detailed surface profile of brushed-eroded enamel and dentin, showing that the composition of the dentifrice and the type of substrate influence the obtained results.

Additional studies are necessary to evaluate the tooth chemical resistance, hardness and other properties of enamel and dentin subjected to different dentifrices with different active ingredients.

\section{Acknowledgments}

The authors would like to thank the Fundação de Amparo à Pesquisa do Estado de São Paulo (FAPESP) (Grant numbers 2005/50811-9 and 2007/07984-5).

\section{References}

Aguiar, J. D., Medeiros, I. S., Souza Junior, M. H. S., \& Loretto, S. C. (2017). Influence of the extended use of desensitizing toothpastes on dentin bonding, microhardness and roughness. Brazilian dental journal, 28(3), 346-353.

Bartlett, D. (2006). Intrinsic causes of erosion. In Dental Erosion. (Vol.20, pp.119-139), Karger Publishers.

Berkathullah, M., Farook, M. S., \& Mahmoud, O. (2018). The Effectiveness of Remineralizing Agents on Dentinal Permeability. BioMed research international, 2018.

Crastechini, E., Borges, A., \& Torres, C. (2018). Effect of Remineralizing Gels on Microhardness, Color and Wear Susceptibility of Bleached Enamel. Operative dentistry.

Crastechini, E., Borges, A., \& Torres, C. (2019). Effect of Remineralizing Gels on Microhardness, Color and Wear Susceptibility of Bleached Enamel. Operative dentistry, 44(1), 76-87.

de Queiroz, A. S., dos Santos, I. R., da Mota Martins, V., de Oliveira Andrade, C. M., Dietrich, L., Nascimento, F., \& dos Reis, T. A. (2021). A influência do dentifrício na abrasividade da estrutura dentinária: uma revisão narrativa. Research, Society and Development, 10(14), e210101421985-e210101421985.

Faller, R. V., Eversole, S. L., \& Tzeghai, G. E. (2011). Enamel protection: a comparison of marketed dentifrice performance against dental erosion. American journal of dentistry, 24(4), 205.

Featherstone, J., Cutress, T., Rodgers, B., \& Dennison, P. (1982). Remineralization of artificial caries-like lesions in vivo by a self-administered mouthrinse or paste. Caries Research, 16(3), 235-242.

Ferreira, S. S., Scaramucci, T., Hara, A. T., Aoki, I. V., \& Sobral, M. A. P. (2015). Supplementation of an Orange Juice with Dietary Proteins to Prevent Enamel and Dentin Erosion. Brazilian dental journal, 26(3), 263-267.

Fita, K., \& Kaczmarek, U. (2016). The Impact of Selected Fluoridated Toothpastes on Dental Erosion in Profilometric Measurement. Advances in clinical and experimental medicine: official organ Wroclaw Medical University, 25(2), 327-333. 
Ganss, C., Klimek, J., Brune, V., \& Schürmann, A. (2004). Effects of two fluoridation measures on erosion progression in human enamel and dentine in situ. Caries Research, 38(6), 561-566.

Gomes, R. N. S., Bhattacharjee, T. T., Carvalho, L. F. C., \& Soares, L. E. S. (2017). Fast monitoring of tooth erosion caused by medicaments used in the treatment of respiratory diseases by ATR-FTIR and $\mu$-EDXRF analysis. Lasers in medical science, 1-10.

Gomes, R. N. S., Bhattacharjee, T. T., Carvalho, L. F. C., \& Soares, L. E. S. (2018). ATR-FTIR spectroscopy and $\mu$-EDXRF spectrometry monitoring of enamel erosion caused by medicaments used in the treatment of respiratory diseases. Microscopy Research and Technique, 81(2), 220-227.

Gomes, R. N. S., Bhattacharjee, T. T., Carvalho, L. F. C., \& Soares, L. E. S. (2019). Adverse effects of respiratory disease medicaments and tooth brushing on teeth: A scanning electron microscopy, X-ray fluorescence and infrared spectroscopy study. Microscopy Research and Technique.

Ionta, F. Q., dos Santos, N. M., Mesquita, I. M., Dionísio, E. J., Cruvinel, T., Honório, H. M., \& Rios, D. (2019). Is the dentifrice containing calcium silicate, sodium phosphate, and fluoride able to protect enamel against chemical mechanical wear? An in situ/ex vivo study. Clinical oral investigations, 1-8.

João-Souza, S. H., Scaramucci, T., Borges, A. B., Lussi, A., Carvalho, T. S., \& Aranha, A. C. C. (2019). Influence of desensitizing and anti-erosive toothpastes on dentine permeability: An in vitro study. Journal of dentistry, 89, 103176.

Joiner, A., Schäfer, F., Naeeni, M. M., Gupta, A. K., \& Zero, D. T. (2014). Remineralisation effect of a dual-phase calcium silicate/phosphate gel combined with calcium silicate/phosphate toothpaste on acid-challenged enamel in situ. Journal of dentistry, 42, S53-S59.

Kyaw, K., Otsuki, M., Segarra, M., Hiraishi, N., \& Tagami, J. (2018). Effect of Calcium-phosphate Desensitizers on Staining Susceptibility of Acid-eroded Enamel. Operative dentistry.

Lombardini, M., Ceci, M., Colombo, M., Bianchi, S., \& Poggio, C. (2014). Preventive effect of different toothpastes on enamel erosion: AFM and SEM studies. Scanning: The Journal of Scanning Microscopies, 36(4), 401-410.

Lussi, A., \& Jaeggi, T. (2006). Chemical factors. In Dental Erosion (Vol. 20, pp. 77-87): Karger Publishers.

Lussi, A., Schlüter, N., Rakhmatullina, E., \& Ganss, C. (2011). Dental erosion-an overview with emphasis on chemical and histopathological aspects. Caries Research, 45(Suppl. 1), 2-12.

Magalhaes, A. C., Wiegand, A., \& Buzalaf, M. A. R. (2014). Use of dentifrices to prevent erosive tooth wear: harmful or helpful? Brazilian oral research, 28 (SPE), $1-6$

Malkoc, M. A., Taşdemir, S. T., Ozturk, A. N., Ozturk, B., \& Berk, G. (2011). Effects of laser and acid etching and air abrasion on mineral content of dentin. Lasers in medical science, 26(1), 21-27.

Maltarollo, T. H., Pedron, I. G., Medeiros, J. M. F., Kubo, H., Martins, J. L., \& Shitsuka, C. (2020). A erosão dentária é um problema! Research, Society and Development, 9(3), e168932723-e168932723.

Nahorny, S., Zanin, H., Christino, V. A., Marciano, F. R., Lobo, A. O., \& Soares, L. E. S. (2017). Multi-walled carbon nanotubes/graphene oxide hybrid and nanohydroxyapatite composite: A novel coating to prevent dentin erosion. Materials Science and Engineering: C, 79, 199-208.

Nova, P. R. d. M. V., Lins Filho, P. C., Dias, M. F., Teixeira, H. M., Cardoso, S. O., \& Lima, M. E. M. (2021). The effect of commercial herbal toothpastes on dental wear: a comparative evaluation by Optical coherence tomography. Research, Society and Development, 10(11), e161101119583-e161101119583.

Oliveira, P. H. C., Oliveira, M. R. C., Oliveira, L. H. C., Sfalcin, R. A., Pinto, M. M., Rosa, E. P., \& Bussadori, S. K. (2019). Evaluation of Different Dentifrice Compositions for Increasing the Hardness of Demineralized Enamel: An in Vitro Study. Dentistry journal, 7(1), 14.

Olley, R. C., Pilecki, P., Hughes, N., Jeffery, P., Austin, R. S., Moazzez, R., \& Bartlett, D. (2012). An in situ study investigating dentine tubule occlusion of dentifrices following acid challenge. Journal of dentistry, 40(7), 585-593.

Ortiz, A. d. C., Tenuta, L. M. A., Tabchoury, C. P. M., \& Cury, J. A. (2016). Anticaries potential of low fluoride dentifrices found in the Brazilian market. Brazilian dental journal, 27(3), 298-302.

Parker, A. S., Patel, A. N., Al Botros, R., Snowden, M. E., McKelvey, K., Unwin, P. R., \& Peruffo, M. (2014). Measurement of the efficacy of calcium silicate for the protection and repair of dental enamel. Journal of dentistry, 42, S21-S29.

Passos, V. F., Melo, M. A., Vasconcellos, A. A., Rodrigues, L. K., \& Santiago, S. L. (2013). Comparison of methods for quantifying dental wear caused by erosion and abrasion. Microscopy Research and Technique, 76(2), 178-183.

Petrou, I., Heu, R., Stranick, M., Lavender, S., Zaidel, L., Cummins, D., \& Gimzewski, J. K. (2009). A breakthrough therapy for dentin hypersensitivity: how dental products containing $8 \%$ arginine and calcium carbonate work to deliver effective relief of sensitive teeth. Journal of Clinical Dentistry, 20(1), 23.

Poggio, C., Gulino, C., Mirando, M., Colombo, M., \& Pietrocola, G. (2017). Preventive effects of different protective agents on dentin erosion: An in vitro investigation. Journal of clinical and experimental dentistry, 9(1), e7.

Poggio, C., Lombardini, M., Vigorelli, P., Colombo, M., \& Chiesa, M. (2014). The role of different toothpastes on preventing dentin erosion: An sem and afm study®. Scanning: The Journal of Scanning Microscopies, 36(3), 301-310.

Sanchez, A. Y., de Oliveira, C. L., Negrini, T. C., Hashizume, L. N., Hara, A. T., Maltz, M., \& Arthur, R. A. (2018). In situ effect of arginine-containing dentifrice on plaque composition and on enamel demineralization under distinct cariogenic conditions. Caries Research, 52(6), 588-597.

Shellis, R., Barbour, M., Jones, S., \& Addy, M. (2010). Effects of pH and acid concentration on erosive dissolution of enamel, dentine, and compressed hydroxyapatite. European journal of oral sciences, 118(5), 475-482. 
Soares, L. E. S., da Silva Magalhães, J., Marciano, F. R., \& Lobo, A. O. (2018). Surface characteristics of a modified acidulated phosphate fluoride gel with nano-hydroxyapatite coating applied on bovine enamel subjected to an erosive environment. Microscopy Research and Technique.

Soares, L. E. S., \& De Carvalho Filho, A. C. B. (2015). Protective effect of fluoride varnish and fluoride gel on enamel erosion: roughness, SEM-EDS, and $\mu$-EDXRF studies. Microscopy research and technique, 78(3), 240-248.

Soares, L. E. S., do Espirito Santo, A. M., Brugnera, A., Zanin, F. A. A., \& Martin, A. A. (2009). Effects of Er: YAG laser irradiation and manipulation treatments on dentin components, part 2: energy-dispersive X-ray fluorescence spectrometry study. Journal of biomedical optics, 14(2), 024002-024002024007.

Soares, L. E. S., Martin, O. C. L., Moriyama, L. T., Kurachi, C., \& Martin, A. A. (2013). Relationship between the chemical and morphological characteristics of human dentin after Er: YAG laser irradiation. Journal of biomedical optics, 18(6), 068001-068001.

Soares, L. E. S., Melo, T. M. T., de Sá Brandim, A., \& de Oliveira, I. R. (2019). Chemical and morphological evaluation of enamel and dentin near cavities restored with conventional and zirconia modified glass ionomer subjected to erosion-abrasion. Microscopy Research and Technique.

Sullivan, R., Rege, A., Corby, P., Klaczany, G., Allen, K., Hershkowitz, D., \& Wolff, M. (2014). Evaluation of a dentifrice containing 8\% arginine, calcium carbonate, and sodium monofluorophosphate to prevent enamel loss after erosive challenges using an intra-oral erosion model. The Journal of clinical dentistry, 25(1 Spec No A), A7-13.

Sun, Y., Li, X., Deng, Y., Sun, J. N., Tao, D., Chen, H., . . . Feng, X. (2014). Mode of action studies on the formation of enamel minerals from a novel toothpaste containing calcium silicate and sodium phosphate salts. Journal of dentistry, 42, S30-S38.

ten Gate, J., \& Imfeld, T. (1996). Dental erosion, summary. European Journal of Oral Sciences, 104(2), 241-244.

Tenuta, L. M., \& Cury, J. A. (2013). Laboratory and human studies to estimate anticaries efficacy of fluoride toothpastes. In Toothpastes (Vol. 23, pp. 108124): Karger Publishers.

Vogel, G. L., Mao, Y., Chow, L. C., \& Proskin, H. (2000). Fluoride in plaque fluid, plaque, and saliva measured for 2 hours after a sodium fluoride monofluorophosphate rinse. Caries Research, 34(5), 404-411.

Walsh, T., Worthington, H. V., Glenny, A. M., Appelbe, P., Marinho, V. C., \& Shi, X. (2010). Fluoride toothpastes of different concentrations for preventing dental caries in children and adolescents. Cochrane database of systematic reviews(1).

Walsh, T., Worthington, H. V., Glenny, A. M., Marinho, V. C., \& Jeroncic, A. (2019). Fluoride toothpastes of different concentrations for preventing dental caries. Cochrane database of systematic reviews(3).

West, N., He, T., Macdonald, E., Seong, J., Hellin, N., Barker, M., \& Eversole, S. (2017). Erosion protection benefits of stabilized SnF 2 dentifrice versus an arginine-sodium monofluorophosphate dentifrice: results from in vitro and in situ clinical studies. Clinical oral investigations, 21(2), 533-540.

Wood, N. J., Jones, S. B., Chapman, N., Joiner, A., Philpotts, C. J., \& West, N. X. (2018). An interproximal model to determine the erosion-protective effect of calcium silicate, sodium phosphate, fluoride formulations. Dental Materials, 34(2), 355-362. 